\title{
"There Is Freedom of Religion in Finland, But...” The Helsinki Mosque Debate
}

\author{
Teemu Pauha and Johanna Konttori
}

\begin{abstract}
In this chapter, we examine statements of Finnish municipal election candidates regarding plans to build a "grand mosque" and cultural centre in central Helsinki. Despite proclaiming support for the universal freedom of religion, the candidates were hesitant to apply it to the mosque case. Opponents of the mosque project emphasized the Christian heritage of Finland and portrayed the proposed mosque as a channel through which foreign conflicts could enter Finnish society. The mosque was also opposed because it was seen as a "political" project instead of a "religious" one. The proponents of the mosque, in turn, considered it to be a "Muslim church" and therefore entitled to the same treatment as Christian houses of worship. The mosque was also seen as important to the local Muslim community, but very few candidates considered the possibility of the mosque (or Islam) making a positive contribution to the broader society. Besides identifying the key discourses, we reflect on them from a religious literacy perspective.
\end{abstract}

Keywords Finland $\cdot$ Helsinki $\cdot$ Religious literacy $\cdot$ Discourse $\cdot$ Election • Islam • Mosque

\section{Introduction}

The sociologist of religion Grace Davie has written about the factors that should be taken into account when talking about religion in present-day Europe. These factors include, among others, the role that Christianity has played-and still plays - in European societies, immigration to Europe from different parts of the world (which has shaped - and still shapes — the religious field of the continent), and the growing realization that regarding religions and religiosity, Europe is not the model that the rest of the world follows. In particular, Muslims challenge the traditional ideas, models and customs of Europe, even by their mere presence. (Davie and Dinham 2019, 17-22.)

\footnotetext{
T. Pauha $(\bowtie) \cdot$ J. Konttori

University of Helsinki, Helsinki, Finland

e-mail: teemu.pauha@helsinki.fi
} 
The number of Muslims in Western Europe has grown rapidly since the Second World War, and in many European countries Islam is now the second largest religion. This change has sparked many political discussions and debates, many of which have dealt with visible signs of Islamic faith in the predominantly Christian/secular European landscape. Two aspects in particular have aroused suspicions and opposition: the use of hijabs and niqabs (Nilsson 2018; Konttori 2015; Brems 2014) and the building and financing of mosques, including the training of the imams working there (Hashas et al. 2018; Allievi 2009; Cesari 2005).

The discussions and debates concerning Islam and Muslims have varied in their intensity from country to country, but nevertheless they exist in most Western European countries in one form or another. Finland is no exception. While a small Tatar community has been living in the country for more than a century, and controversies and debates rarely concern them in any way, the majority of Muslims in Finland who immigrated from the early 1990s onwards have received much more attention from the media, politicians and ordinary citizens. Questions concerning headscarves, niqabs, mosques, burial and butchery practices have been raised in Finland, but the discussions have remained relatively calm.

Currently there are only two purpose-built mosque buildings in Finland. These are situated in the small town of Järvenpää and in Helsinki, respectively, and belong to the Tatars. In January 2015, a conglomerate of two Muslim organisations and an interfaith dialogue group applied for land to build a "grand mosque" and cultural centre in central Helsinki. The conglomerate wanted to keep the mosque independent of existing Muslim associations, and therefore it created a separate foundation named Oasis to manage its affairs. (Pauha and Konttori 2019.) The Helsinki mosque project was debated for several years, receiving a great deal of attention, at least in the capital region.

One of the main issues during the mosque debate concerned foreign funding. The organizers of the mosque project had negotiated with Bahrain, and there were fears that with outside money there would also come foreign influence in relation to the type of Islam practised in Finland. In addition, the estimated building costs of the mosque were quite high, totalling over 100 million Euros, and the maintenance costs would also have been considerable. These aspects led to astonishment and drew criticism. Another issue was the representativeness of the mosque. It was supposed to be open to all Muslims, but doubts arose whether in practice the Shi' a would be included. Furthermore, not all Muslim communities active in Helsinki were supportive of the project. (Pauha and Konttori 2019; see also Pauha and Martikainen 2017.)

In December 2017, the Urban Environment Division of the City of Helsinki proposed that the Urban Environment committee accept the application and reserve a plot for the mosque complex, albeit with conditions. Despite this, the committee unanimously rejected the application in a meeting held the very next week. The committee concluded that the application was untenable because "the scope of the project and the still open questions and uncertainty factors, above all the origin of the funding and the possible effects of the funding sources, do not provide a sustainable foundation for this solution to be realized." The mosque plan was scheduled to be further discussed by the City Board of Helsinki, but after it was rejected by the Urban 
Environment committee, the applicants decided to withdraw the application. (Pauha and Konttori 2019.)

In this chapter, we investigate comments made by electoral candidates in the Helsinki City Council election in Spring 2017 and study how they argued either for or against the mosque plan. The data consists of the responses given by the candidates to a specific statement presented by the leading daily newspaper in Finland, the Helsingin Sanomat: "It is possible to build a grand mosque for Helsinki if no city or state money is spent on the project." The candidates were asked to rate on a scale of 1-5 whether they agreed with the statement or not, with 1 meaning "totally disagree", 3 meaning "don't know", and 5 meaning "totally agree". Altogether 848 candidates gave their rating. The distribution of responses is shown in Table 1.

As can be seen in the last row of Table 1, approximately one third of the candidates were at least somewhat opposed to the mosque project, while little over half were in favour of it. Opposition to the mosque was strongest among the candidates of the populist-nationalist Finns Party, centre-right National Coalition Party, Independence Party (known for being Eurosceptic), and Christian Democrats, while the candidates of all other parties were generally in favour of the project.

Besides giving numerical ratings, the candidates could justify their answers by writing open responses. Altogether 630 out of 848 respondents chose to do so. In the rest of this chapter, we focus on those 630 responses. We have coded their contents in a bottom-up manner, that is, without a pre-existing coding scheme, using the following questions as guidance: How are Islam in general and the mosque project in particular represented in the data? How do the candidates understand religion and its role in society? What are the blind spots regarding religion in their statements?

We identified several key discourses - ways of representing the issue at handthat underlie the responses. In the following we take a closer look at these discourses, pointing out the main lines of argumentation as well as the rhetorical choices made to strengthen the candidates' arguments. In order to exemplify each discourse we present several illustrative quotes from the data.

We reflect on the discourses from a religious literacy perspective. We understand religious literacy in the vein of Moore (2007, p. 56) as "the ability to discern and analyze the fundamental intersections of religion and social/political/cultural life through multiple lenses". We have chosen Moore's approach to religious literacy because of the emphasis that it places on complex interconnections between religious and other aspects of social reality. As will be seen in the following pages, religion is often perceived as problematic insofar as it intertwines with politics. This is especially the case with Islam; in public discussion, Islam is regularly portrayed as something inextricably political, even to the extent of being "politics in religious disguise". Accordingly, many of the responses analysed here argue that religion and politics need to be kept separate, or otherwise they will taint each other. Moore $(2007,2015)$, however, thinks differently. For her, the intertwining of religion and politics is not a problem in itself. Rather, it is just the way things are. Religion is always to some extent political, and vice versa. Religious literacy is about discerning the subtle ways in which religion intersects with other fields of human activity. 
Table 1 The distribution of responses ( 1 = "totally disagree", $3=$ "don't know", $5=$ "totally agree") given to the statement: "It is possible to build a grand mosque to Helsinki, if no city or state money is spent on the project."

\begin{tabular}{|c|c|c|c|c|c|c|}
\hline Party & 1 & 2 & 3 & 4 & 5 & Total \\
\hline $\begin{array}{l}\text { Social } \\
\text { Democratic } \\
\text { Party }\end{array}$ & $11(9.6 \%)$ & $\begin{array}{l}19 \\
(16.5 \%)\end{array}$ & $\begin{array}{l}17 \\
(14.8 \%)\end{array}$ & $\begin{array}{l}51 \\
(44.3 \%)\end{array}$ & $\begin{array}{l}17 \\
(14.8 \%)\end{array}$ & $\begin{array}{l}115 \\
(100.0 \%)\end{array}$ \\
\hline Centre Party & $4(5.4 \%)$ & $\begin{array}{l}13 \\
(17.6 \%)\end{array}$ & $6(8.1 \%)$ & $\begin{array}{l}30 \\
(40.5 \%)\end{array}$ & $\begin{array}{l}21 \\
(28.4 \%)\end{array}$ & $\begin{array}{l}74 \\
(100.0 \%)\end{array}$ \\
\hline $\begin{array}{l}\text { National } \\
\text { Coalition } \\
\text { Party }\end{array}$ & $\begin{array}{l}21 \\
(18.9 \%)\end{array}$ & $\begin{array}{l}48 \\
(43.2 \%)\end{array}$ & $6(5.4 \%)$ & $\begin{array}{l}29 \\
(26.1 \%)\end{array}$ & $7(6.3 \%)$ & $\begin{array}{l}111 \\
(100.0 \%)\end{array}$ \\
\hline $\begin{array}{l}\text { Swedish } \\
\text { People's } \\
\text { Party }\end{array}$ & $1(2.0 \%)$ & $8(16.3 \%)$ & $5(8.2 \%)$ & $\begin{array}{l}29 \\
(59.2 \%)\end{array}$ & $7(14.3 \%)$ & $\begin{array}{l}49 \\
(100.0 \%)\end{array}$ \\
\hline $\begin{array}{l}\text { Christian } \\
\text { Democrats }\end{array}$ & $\begin{array}{l}39 \\
(54.9 \%)\end{array}$ & $\begin{array}{l}15 \\
(21.1 \%)\end{array}$ & $6(8.5 \%)$ & $9(12.7 \%)$ & $2(2.8 \%)$ & $\begin{array}{l}71 \\
(100.0 \%) \\
\end{array}$ \\
\hline $\begin{array}{l}\text { Green } \\
\text { League }\end{array}$ & $1(0.8 \%)$ & $9(7.3 \%)$ & $\begin{array}{l}13 \\
(10.6 \%)\end{array}$ & $\begin{array}{l}65 \\
(52.8 \%)\end{array}$ & $\begin{array}{l}35 \\
(28.5 \%)\end{array}$ & $\begin{array}{l}123 \\
(100.0 \%)\end{array}$ \\
\hline Left Alliance & $5(4.8 \%)$ & $9(8.6 \%)$ & $10(9.5 \%)$ & $\begin{array}{l}56 \\
(53.3 \%)\end{array}$ & $\begin{array}{l}25 \\
(23.8 \%)\end{array}$ & $\begin{array}{l}105 \\
(100.0 \%)\end{array}$ \\
\hline Finns Party & $\begin{array}{l}62 \\
(72.1 \%)\end{array}$ & $\begin{array}{l}10 \\
(11.6 \%)\end{array}$ & $3(3.5 \%)$ & $7(8.1 \%)$ & $4(4.7 \%)$ & $\begin{array}{l}86 \\
(100.0 \%) \\
\end{array}$ \\
\hline $\begin{array}{l}\text { Communist } \\
\text { Party }\end{array}$ & $3(8.1 \%)$ & $4(10.8 \%)$ & $2(5.4 \%)$ & $\begin{array}{l}15 \\
(40.5 \%)\end{array}$ & $\begin{array}{l}13 \\
(35.1 \%)\end{array}$ & $\begin{array}{l}37 \\
(100.0 \%)\end{array}$ \\
\hline Liberal Party & $0(0.0 \%)$ & $3(20.0 \%)$ & $2(13.3 \%)$ & $5(33.3 \%)$ & $5(33.3 \%)$ & $\begin{array}{l}15 \\
(100.0 \%)\end{array}$ \\
\hline Pirate Party & $2(8.3 \%)$ & $2(8.3 \%)$ & $1(4.2 \%)$ & $7(29.2 \%)$ & $\begin{array}{l}12 \\
(50.0 \%)\end{array}$ & $\begin{array}{l}24 \\
(100.0 \%) \\
\end{array}$ \\
\hline $\begin{array}{l}\text { Feminist } \\
\text { Party }\end{array}$ & $1(4.3 \%)$ & $6(26.1 \%)$ & $0(0.0 \%)$ & $\begin{array}{l}14 \\
(60.9 \%)\end{array}$ & $2(8.7 \%)$ & $\begin{array}{l}23 \\
(100.0 \%)\end{array}$ \\
\hline $\begin{array}{l}\text { Independence } \\
\text { Party }\end{array}$ & $4(57.1 \%)$ & $1(14.3 \%)$ & $1(14.3 \%)$ & $1(14.3 \%)$ & $0(0.0 \%)$ & $7(100.0 \%)$ \\
\hline Other ${ }^{\mathrm{a}}$ & $2(25.0 \%)$ & $1(12.5 \%)$ & $0(0.0 \%)$ & $3(37.5 \%)$ & $2(25.0 \%)$ & $8(100.0 \%)$ \\
\hline Total & $\begin{array}{l}156 \\
(18.4 \%)\end{array}$ & $\begin{array}{l}148 \\
(17.5 \%)\end{array}$ & $71(8.4 \%)$ & $\begin{array}{l}321 \\
(37.9 \%)\end{array}$ & $\begin{array}{l}152 \\
(17.9 \%)\end{array}$ & $\begin{array}{l}848 \\
(100.0 \%)\end{array}$ \\
\hline
\end{tabular}

aThe "Other" category includes independent candidates and parties with three or fewer candidates (e.g. the Animal Justice Party and Communist Workers' Party)

Moore (2015) advocates a cultural studies approach as an antidote to diminishing religious literacy. According to her, such an approach entails, for example, three central claims with regard to religion: first, religions are not monolithic but internally diverse; secondly, religions are not static but evolving and changing; and lastly, religions do not function in an isolated "religious" sphere but influence all aspects of culture. As we will demonstrate in the following pages, these three claims can 
provide a valuable corrective to the blind spots demonstrated by the comments of the electoral candidates.

We argue that even in a secular country, politicians need to have knowledge about religions in order to be able to make fact-based decisions on issues related to religions and religious communities. Questions regarding religious literacy do not concern only Islam, but they still often have something to do with it, especially in contemporary Western Europe, where the number of Muslims and the significance of Islam have grown rapidly.

\section{Domestic Christianity, Foreign Islam}

The first hegemonic discourse that we identified in our data constructs a juxtaposition between Christianity and Islam, with the former as something Finnish while the latter is not. Several of the responses mentioned conflicts that would supposedly be caused by the mosque. These conflicts were typically portrayed as imported from abroad. The general idea appeared to be that foreign funding would be accompanied by a radical agenda that in some unspecified way might permeate into the Finnish Muslim community. The idea that radicalism could develop inside the Finnish Muslim community without foreign involvement was not taken into account. Both of these ideas held religious ideologies and communities to be static: if the foreign funder had some sort of an agenda, it would simply be transferred to Finland, and Muslims in the country would accept it without any critical thinking.

On the other hand, the transfer of the conservative thoughts of the foreign funders to the Finnish Muslim population causes threatening visions. (Male, Liberal Party, 4) ${ }^{1}$

No Saudi money for Helsinki. It does not come free of charge. Elsewhere radicalization has been significant in mosques funded by Saudi Arabia. (Male, Finns Party, 1)

In the latter statement, it is noted (with no further specification) that funding of a mosque by Saudi Arabia has led to radicalization "elsewhere". This is one of the many examples of how the Helsinki mosque debate was transnational by nature. Several respondents referred to experiences in other countries, and thus the debate was never only about Helsinki and Finland. Quite obviously, this also has a lot to do with the fact that the funding of the mosque was coming from abroad. The transnational aspect of the debate will be discussed further on.

Another thing to note is the vagueness of the statement. The respondent does not give any indication of which countries or mosques he is referring to. The statement gives the impression that the respondent has studied the issue, as he is referring to previous mosque projects, but the vagueness actually takes a lot of credibility away. While it is true that foreign funding and influence over European Muslims has had effects in the European context (see, e.g., Rohe 2019), it would be too

\footnotetext{
${ }^{1}$ The number in parentheses refers to the numerical rating ( $1=$ "totally disagree", $3=$ "don't know", $5=$ "totally agree") given to the statement: "It is possible to build a grand mosque to Helsinki, if no city or state money is spent on the project."
} 
much to claim that all of the Saudi-funded mosques in Europe are extremist or radical actors (Inge 2016, 28-29). The word "elsewhere" in the statement gives the impression that Saudi funding and radicalization go hand in hand. Also, and quite interestingly, in statements which bring up the threat of radicalization in Finland there is no specification of who would bring that radicalization. One possible actor could be imams. Whether imams should be trained in Europe or, for example, in Saudi Arabia has been debated and investigated in many European countries (Hashas et al. 2018), Finland included (Martikainen and Latvio 2018). It is somewhat surprising that imams were only rarely mentioned in the data.

The fear of radicalization being brought from abroad is evident in the following statement as well:

As far as we know, the funding would come from actors supportive of the ultraconservative

Salafi branch of Islam, which might further the spread of radical thought in Finland. (Male,

Liberal Party, 2)

Why was radicalization perceived solely as a threat from abroad? Arguably, this may demonstrate the extent to which popular conceptions of Islam are based on media coverage. Raittila and Maasilta (2008) have noted that when discussing Islam in other countries, Finnish newspapers have a strong tendency to associate it with terrorism and political violence. However, the same kind of association is not made in newspaper stories that are about Islam and Muslims in Finland. When Finnish Muslims are described as being involved in conflicts, the conflicts are between Islamic religious practices and the Finnish legislation, and not violent in nature. (Raittila and Maasilta 2008.)

The statement above also mentions "the ultraconservative Salafi branch of Islam", linking it to "radical thought". As Inge (2016) has noted, Salafism is often assumed to be both a political and (potentially) violent movement, even though the opposite is often the truth. Here, religious illiteracy appears to manifest itself in the form of a lack of knowledge. Inge conducted her research on Salafi women in London and Birmingham, and she notes that all of the Salafi communities that she got to know during her fieldwork were categorically against both political action and violence. We cannot know for sure what the candidate of the Liberal Party meant by "radical thought", but at least some connection with either political or violent action can be assumed.

All in all, it remains unclear whether the candidates were primarily worried about violent extremism or anti-liberal values, because they associated the mosque project (with little elaboration) with both. However, as Moore (2015) has emphasized, religious literacy involves an awareness of the internal diversity of religious traditions. It is necessary, for example, to acknowledge the distinction between religious conservatism and religiously motivated violence. Conservative religious groups, both Islamic and otherwise, can be opposed to issues such as gender equality and democracy, without this translating into violent extremist action.

Besides the potential for conflicts associated with the mosque, Islam in general was often portrayed as foreign and Christianity as the religion of Finland. It appears 
that a large mosque was seen to be too dominant in the Christian environment and culture, according to the respondents.

Finland is still a Christian country. (Female, Christian Democrats, 1)

A grand mosque does not fit into the Finnish culture and our way of life. (Male, National Coalition Party, 1)

Finland is a Christian country. It is not allowed to build large Christian churches in any Muslim country, and in many cases not any kind of Christian shrine is allowed. (Male, Social Democratic Party, 1)

The transnational nature of the debate is again visible in the statement in which it is pointed out that Christians are not allowed to build large churches in Muslim countries. This statement implicitly suggests that if Christians are not allowed to build churches in Muslim countries, then Muslims should not be allowed to build a grand mosque in a Christian country.

The idea of the foreignness of Islam was often conveyed implicitly by unquestioningly assuming that Muslims in Finland are immigrants. An example of this is the following excerpt, which refers to the "home country" of the Muslims. While it remains unclear what the country in question is, the choice of words shows that it is certainly not Finland.

I do not think that the Shias and the Sunnis would be able to practise their religion in the same mosque, as they are not able to do that even in their home country. (Female, Christian Democrats, 1)

As demonstrated by the examples above, many of the respondents consider Finland to be a "Christian country" or "Christian state". This is in line with Davie's point, presented earlier, on the significance of Christian heritage in Europe. Coming from an election candidate, the notion of the Finnish state as "Christian" is problematic because, at least in the legal sense, it is untrue; despite granting special judicial status to the Evangelical Lutheran Church and Orthodox Church, Finland has no official religion, and the state is confessionally neutral (Kääriäinen 2011; Sorsa 2015). However, as discussed in Pauha (2018) and Pauha and Jasinskaja-Lahti (2013), the public representations of Finnishness are still very much intertwined with Christianity; this may maintain the idea of a homogeneously Christian state and, as a result, exclude religious minorities from perceptions of true Finnishness.

The notion of the Finnish state as "Christian" is especially noteworthy, as it comes from candidates wishing to represent the capital of Finland. As in many other European countries, (Muslim) immigrants to Finland tend to live in the biggest cities. Accordingly, Helsinki is probably the most multicultural city in Finland, and its inhabitants confess an array of different faiths. In this context, the emphasis put on a "Christian" Finland may represent an ideal held by a candidate, but it hardly reflects the multireligious reality in the city, in which approximately one half of the inhabitants are not members of the majority church (Helsingin seurakuntayhtymä 2018). 


\section{Contested Boundaries of Religion}

A particularly prominent discourse concerned the freedom of religion and its limits. Regardless of party affiliation, candidates emphasized the necessity for religious freedom and the equal treatment of all religions by the state. In the very next instant, however, they often gave reasons for restricting these rights in the case of the Helsinki mosque project. Frequently used were statements in the vein of "there is freedom of religion in Finland, but..." Examples of this discourse include:

In the name of freedom of religion, it is of course allowed to build shrines of different religions in Helsinki, but on the basis of existing knowledge, I do not support this project. (Male, Green League, 2)

People of all religious denominations need to have their place in Helsinki for religious practice, but there have been bad experiences of grand mosques elsewhere in the world. (Female, National Coalition Party, 1)

In the statement above, the mosque debate is once again linked to previous experiences "elsewhere in the world", and thus the transnational aspect of the debate is brought up. And again, the statement includes a vague reference to somewhere else in the world. This vagueness makes it impossible for the voters, or researchers for that matter, to check the claim concerning bad experiences in relation to grand mosques. This is apparent in the following statement as well, where the respondent does not refer only to "bad experiences" but also to hate and terrorism. Again, it is impossible to know which cases the respondent is referring to. Positive examples from "elsewhere" are conspicuously absent. Religious literacy, as understood by Moore, would require that the heterogeneity of Muslim communities and their mosques receive attention. Here Islam and grand mosques are presented only in a problem-oriented manner.

Every religion has the right to have a place where to worship their God. But mosques in other countries have been used to instigate hate and to support terrorism. (Male, Finns Party, 2)

The statements were often very general and abstract with regard to religious freedom. A few candidates even quoted directly from the European Convention on Human Rights or similar treaties. It is not far-fetched to interpret this as an electoral tactic: by making declarations in support of religious freedom, the election candidates could signal their commitment to general democratic values.

Upon close reading of the statements, it appears that many of the candidates were operating on the implicit assumption that true religion excludes politics. Accordingly, the mosque project was perceived as problematic because it was considered to be political instead of religious_-or even political in religious disguise. Some examples include:

The grand mosque is more of a political project than a possibility to practise religion. (Male,

Left Alliance, 1)

Islam is not a religion, but a conservative political ideology. (Female, Finns Party, 1) 
As van der Veer (1996) has illustrated, the idea of true religion as antithetical to politics is the product of Western Enlightenment thought, which restricted the role of religion to the private sphere. True religion, as it is understood in the postEnlightenment West, is about harmony and goodwill, whereas politics is about division and conflict (van der Veer 1996; see Pauha 2017). Similar views on religion are conveyed, for example, in the following excerpts:

The core message of all true religions is the same, namely, the equality of and brotherly love among all people. However, the mosque that is planned for Helsinki would represent Wahhabism, disguised as Islam. (Male, Independence Party, 1)

In this project religion and politics seem to intertwine, and that might put a strain on relations between Muslims representing different denominations. (Female, Green League, 4)

It needs to be ensured that the rationally selected location is for practising one's religion, not for agitating people. (Male, Finns Party, 4)

That Islam is considered to be "political" instead of purely religious is a relatively widespread discourse in contemporary Europe. From a religious literacy perspective, however, such a strict demarcation between religion and other fields of human activity is questionable. Moore $(2015,31)$ emphasizes that religious literacy involves understanding religion "in context and as inextricably woven into all dimensions of human experience" (italics in the original). A religiously literate person is able to look past popular preconceptions about certain religious traditions or religion in general and perceive the complex interconnections between religion and other facets of human culture. In addition, the claim that the mosque "would represent Wahhabism, disguised as Islam", suggests that Wahhabism is not Islam. This is factually incorrect.

Furthermore, as scholars such as Taira $(2010,2013)$ have argued, religion is not a clearly bounded entity to be found in the social world but a classificatory device that can be applied to any number of things in order to advance goals related to them. With the status of religion come certain (both official and unofficial) privileges and burdens. The demarcation of religion is therefore inextricably tied to issues of power and dominance.

Definitions can be used as tools for the governance of religion. The choice of one definition over others may be used to legitimize religious restrictions without appearing to violate the freedom of religion. As we have discussed above, a number of electoral candidates emphasized their commitment to religious freedom while at the same time opposing the proposed mosque. Such a rhetorical move was easier, of course, if the mosque could be placed outside the boundaries of religion. The same strategy has also been used, for example, in political debates in France on headscarves and veils (Konttori 2015).

In contrast to those denying Islam the status of a religion, commentators with a favourable attitude towards the proposed mosque tended to perceive it as a straightforward equivalent of a Christian church. A few of the statements even used the term "church" in reference to a mosque.

I see mosques, just like churches, as places for practising one's religion. (Male, Left Alliance, 5) 
We do, after all, have churches representing other denominations as well. (Male, Left Alliance, 4)

If we have a grand church [referring to Helsinki Cathedral], then why not a grand mosque? (Male, Left Alliance, 4)

It is possible to build a grand mosque, just like the churches of all other religions. (Female, National Coalition Party, 4)

One could question the term "Muslim church" by pointing out that, despite overlapping, the roles of a church and a mosque are not identical. Read in context, however, the choice of words here do not seem to imply a one-to-one correspondence between the functions of the two buildings, but a very general idea of both being houses of worship and therefore entitled to the same treatment. ${ }^{2}$

Besides perceiving the mosque as a "Muslim church", the favourable commentators tended to regard the activities of the mosque as internal affairs of the Muslim community. The mosque plan was welcomed because Muslims were thought to need it. A lack of space was perceived as the most pressing of their needs.

In a situation where there is a lack of prayer rooms and suitable locations for practising religion, the grand mosque is an important project for the Muslim community. (Female, Left Alliance, 5)

Reading the statements, one gets an impression of the Finnish Muslims as a more or less insular community, whose needs do not intersect with those of the broader society. In this case, the needs of the city are held as primary and the needs of the local Muslims as secondary, if they are considered at all. In fact, several candidates justified their numerical rating with a short comment: "Helsinki does not need a grand mosque." However, to quote Sicinius in Shakespeare's Coriolanus (Act 3, Scene 1), "What is the city but the people?" Whether the Muslims of Helsinki were (implicitly or explicitly) included among the inhabitants of the city varied between the responses. Perhaps not surprisingly, recognition of Muslims as inhabitants was often associated with a positive attitude towards the mosque plan.

Muslims have the same right to practise their religion as all other people living in Helsinki. (Female, Left Alliance, 5)

Everyone who lives in Helsinki, no matter their religion, has the right to practise religion in suitable premises, so I support the building of a grand mosque. (Female, Feminist Party, 4)

In my opinion, the grand mosque should be built because it has a big influence on the daily well-being of many people living in Helsinki. (Female, National Coalition Party, 4)

It [the mosque] would not serve the interests of the people of Helsinki. (Male, Centre Party, 1)

However, even those candidates who explicitly included Muslims among the inhabitants of Helsinki very seldom perceived overlaps between the needs of the

\footnotetext{
${ }^{2}$ It is also worth noting that mosques in Europe have adopted functions that are very different from those of mosques in Muslim-majority countries but similar to those of European churches. European mosques, for example, increasingly perform ceremonies such as weddings and funerals. Allievi $(2009,21)$ refers to this as the "Christianization" of mosque functions.
} 
Muslim community and those of the broader society. Indeed, only a few commentators considered the possibility that it could be in the interests of the city and state if the mosque was built. The few exceptions included the following:

With the help of a grand mosque, especially the young people with asylum status could possibly be supported in their integration into Finland, and therefore it could be good for Helsinki if implemented right. (Male, Centre Party, 4)

A grand mosque would enable dialogue between religions and, through that, increasing understanding. (Female, Left Alliance, 5)

The mosque increases the value and diversity of the real estate. (Female, Left Alliance, 4)

It is important that an urban environment that is built in central locations be open and shared by all. Hence, I hope that there will be, for example, suitable restaurants and other services in connection with the mosque. (Male, Green League, 4)

Thus, to summarize, the candidates declared overall support for freedom of religion but were hesitant to apply it to the project at hand. Some candidates even questioned whether the mosque project —or Islam, for that matter-is about religion at all. Instead of being a site of religious practice, the mosque was perceived as a political arena and channel through which foreign conflicts could seep into Finnish society. The possible benefits of the mosque to the city as a whole were ignored by all but a few respondents. In contrast, those favourable to the mosque plan tended to emphasize the equivalence of a church to a mosque as well as the needs of the local Muslim community.

\section{Undefined Fears and Vague Worries}

Sociologist of religion Allievi $(2009,60 ; 2014)$ has analysed European mosque debates and noted that the resistance to mosques can be roughly divided into two categories. On one hand, people are against mosque plans because of the concrete effects that mosques are supposed to have-for example, property value decline, noise, increased traffic, and violent crime. On the other hand, mosques are opposed for cultural reasons, for example, because of perceiving Islam as oppressive to women or otherwise incompatible with European values.

Our data contained examples of both kinds of worries. Quite frequently, however, the actual reasons for the opposition and suspicion were not stated, and the candidates only made vague references to general feelings of worry and concern. Usually the vagueness appeared to stem from a lack of information, especially about the funding sources, but it can also be asked whether at least some of these statements stem from common stereotypes concerning Islam. Be it as it may, if we follow Dinham and Jones $(2010,6)$, a religiously literate person acts based on knowledge, not on stereotypes.

I feel suspicious about the construction of a grand mosque. (Male, Christian Democrats, 2)

Concerns are raised about the mosque funding that possibly comes from outside Finland.

(Female, Christian Democrats, 3) 
The project funding from Bahrain raises questions. (Male, Social Democratic Party, 1)

Funding concerns [me] a lot, too. (Male, National Coalition Party, 2)

At other times, vague statements seemed to imply an underlying presupposition of shared knowledge. The candidates' choice of words expressed confidence in readers knowing beforehand about similar mosques in other countries and about the problems caused by them. The impression was that candidates did not explicate their concerns because they thought it was unnecessary, since readers would get the point.

For an electoral candidate, the avoidance of explicit accusations against Islam may provide protection against being labelled a bigot. Only hinting at problems, instead of naming them outright, allows for some leeway if one is called to answer for one's words.

Experiences from other countries are very bad. (Male, Finns Party, 1)

Experiences from elsewhere are not encouraging. (Male, National Coalition Party, 2)

Grand mosque plans have sadly turned out to be projects by the kind of actors whose aims are not good for the traditional way of life of us Finns. (Male, National Coalition Party, 1)

As illustrated by some of the examples, the electoral candidates often made references to bad experiences around mosques in other countries. Typically, however, the mosques and countries in question were not specified. References to experiences from other countries nevertheless illustrate the transnational aspects of mosque debates. In particular, the arguments used against the building of mosques are often borrowed from other national contexts. (See Allievi 2009, 52-53.) Cautionary tales of extremist mosques are circulated on discussion forums and shared on Facebook. Eventually the tales become disconnected from their original context and turn into common folklore among right-wing nationalists in Europe. Like fables and fairy tales, they are not set in a specific time or place, but serve as a general warning about all mosques.

\section{Conclusion}

When quoting the candidates, we have included their party and gender. All in all, however, such identities appeared to play a small role in the way that arguments for or against the mosque were constructed. Similar arguments were used across party lines, and where there were differences, they were of emphasis, not of kind. Christian Democrats, for example, were especially keen to emphasize the Christian heritage of Finland and the foreignness of Islam, but parallel views appeared in statements across the political spectrum. Altogether, it appears that the discourses presented above are common ways of discussing Islam and not limited to certain political stances. This further supports the argument that the statements analysed here reflect not just the views of individual Finnish politicians, but ideas that are relatively widespread in Finnish society—or in Europe more generally, as discussed in the previous paragraph. 
A key issue dividing the statements is whether Islam is just one religion among many or whether it is a special case. Those favourable to the mosque tended to perceive it as a "Muslim church" and therefore subject to the same laws and regulations as any other house of worship. Those opposing the mosque, in turn, tended to treat Islam as unique. ${ }^{3}$ Islam was perceived as a non-Finnish ideology that threatens to import foreign conflicts into the country. Because of its association with conservative social values and inegalitarianism, some commentators even denied Islam the status of a religion. Such a perception of Islam is, of course, very one-sided and blind to significant religious variation.

Even though the majority of the statements in the data do not explicitly promulgate this kind of alienating discourse, they fail to provide a counter-discourse to it. Perhaps the most typical stance taken in the data is that of "detached suspicion", where the affairs of the Muslim community are seen as being of little relevance to the policymakers. In this case, the only reasons for city officials to be interested in the whole mosque issue are their suspicions surrounding the funding sources and a desire to reserve the same lot of land for some other purpose (for example, apartments). Furthermore, very few statements mention the possibility of a mosque-or Muslims in general - making a valuable contribution to society. This obviously constitutes an additional blind spot in the mosque discussion.

From a religious literacy perspective, treating Islam as a special case is problematic, but so is treating it as a faith like any other. Religious literacy involves the ability to discern both the similarities and differences between-and within-religions. Therefore, simplified characterizations that either equate all religions or define them through opposition should be avoided. Religions are better understood as "pools of stories" (see Pauha and Jasinskaja-Lahti 2013) or as "baskets" (Hjärpe 1997), being collections of disparate and often conflicting narratives, norms, beliefs, and rituals. When crafting their religious identities, religious communities and individual believers choose some things from the basket and leave others. From this perspective, it is fruitless to debate whether Islam is fundamentally a religion of peace or a religion of war. The Islamic basket contains grounds for both interpretations. The mistake made in many of the statements analysed here is in seeing only some contents of the basket and confusing it with the basket as a whole.

What, then, could be done to correct some of the blind spots outlined in this paper? Drawing on Moore's (2015) approach to religious literacy, we would make four suggestions. (1) Like Moore, we want to emphasise the internal diversity of religion. This aspect is often missing in the data. Davie's repeated observation of "a lamentable quality of conversation about religion" in Britain (Dinham 2015, 45) applies, at least up to a certain point, to Finnish public discussions on Islam. Perceptions of Islam and Muslims are all too often based on media images that tend to exaggerate violence and terror. News from conflict zones provide a partial glimpse into Islam, but certainly not

\footnotetext{
${ }^{3}$ Other researchers have also noted (and critiqued) "the snare of exceptionalism" with regard to Islam and mosques in Europe (Cesari 2005, 2007; see also Allievi 2009, 7-9). Instead of treating Islam and Muslims as one religion or minority group among many, policymakers-and also some academics - are prone to perceive them as an exception that needs to be considered separately from other minority and religious issues.
} 
the whole truth (see also Francis et al. 2015, 128-129, on Muslims as a risk or threat). Religious literacy involves a critical attitude towards one-sided media coverage and preparedness to learn the "other side". In fact, as Lövheim (2012) has pointed out, there is a need for religious media literacy.

(2) Another key point raised by Moore is the changing nature of religion. Islam, for example, has gone a long way from being "an Arab religion" to being a collective noun for a diverse set of traditions all around the world. Islam is no longer a foreign religion in Finland, and it should not be treated as such. It is important to be aware of the transnational links between Finnish Muslims and the Middle East, but the role of such links should not be overstated. The relations between Finnish Muslim communities in particular cannot be explained only in terms of Middle Eastern politics.

(3) For Moore, it is important to perceive religion as permeating all aspects of social life. Religion is not, and cannot be, confined to its own separate domain. All initiatives that propose a total exclusion of religion from the public sphere are therefore doomed from the start. Typically, such initiatives place increasing restrictions on certain highly visible forms of religious practice, and at the same time turn a blind eye to other ways in which religion influences public life. For instance, the singing of hymns in school celebrations is often framed as a Finnish national tradition instead of a religious one, and the singing of hymns is thus considered to be permissible in school, even though the practice of religion in general is not. This, in turn, supports the hegemonic position of the dominant Lutheran Church (Taira 2019). A more nuanced understanding of religion and its role in public life may contribute to a more equal society.

(4) In a related vein, Muslims should not be perceived as an enclave isolated from the surrounding city. Muslims are very much part of the city, and what affects the Muslims affects the city. Furthermore, aside from being a Muslim house of worship, a grand mosque is also an important urban landmark. As such, it has functions that go beyond the religious. By organising training and social support, a grand mosque can fill the gaps left by other service providers. It may also attract tourists, host school visits, and serve as an information point for anyone interested in Islam. All these functions should be considered alongside the potential security risks posed by a grand mosque.

\section{References}

Allievi, S. (2009). Conflicts over mosques in Europe: Policy issues and trends. London: Alliance Publishing Trust.

Allievi, S. (2014). Mosques in Western Europe. In Oxford Islamic studies online. Retrieved March 16, 2019, from http://www.stefanoallievi.it/2014/07/mosques-in-western-europe/.

Brems, E. (Ed.). (2014). The experiences of face veil wearers in Europe and the law. Cambridge: Cambridge University Press.

Cesari, J. (2005). Mosque conflict in European cities: Introduction. Journal of Ethnic and Migration Studies, 31(6), 1015-1024. 
Cesari, J. (2007). Muslim identities in Europe: The snare of exceptionalism. In A. Al-Azmeh, \& E. Fokas (Eds.), Islam in Europe. Diversity, identity and influence (pp. 49-67). Cambridge: Cambridge University Press.

Davie, G., \& Dinham, A. (2019). Religious literacy in modern Europe. In A. Melloni, \& F. Cadeddu (Eds.), Religious literacy, law and history. Perspectives on European pluralist societies (pp. 17 28). London: Routledge.

Dinham, A. (2015). Grace Davie and religious literacy: Undoing a lamentable quality of conversation. In A. Day \& M. Lövheim (Eds.), Modernities, memory and mutations: Grace Davie and the study of religion (pp. 45-58). Farnham: Ashgate.

Dinham, A., \& Jones, S. H. (2010). Religious literacy leadership in higher education: An analysis of key issues and challenges for university leaders. Report. Religious Literacy Leadership in Higher Education Programme, York. Retrieved March 20, 2019, from http://research.gold.ac.uk/ id/eprint/3916.

Francis, M., van Eck, A., \& van Twist, D. (2015). Religious literacy, radicalisation and extremism. In A. Dinham \& M. Francis (Eds.), Religious literacy in policy and practice (pp. 113-134). Bristol: Policy Press.

Hashas, M., de Ruiter, J. J., \& Vinding, N. V. (Eds.). (2018). Imams in Western Europe. Developments, transformations and institutional challenges. Amsterdam: Amsterdam University Press.

Helsingin seurakuntayhtymä. (2018). Jäsentietojen vuositilasto 2017. Retrieved March 13, 2019, from https://www.helsinginseurakunnat.fi/material/attachments/Ivt3wLwql/vuositilasto_ 2017.pdf.

Hjärpe, J. (1997). What will be chosen from the Islamic basket? European Review, 5(3), 267-274.

Inge, A. (2016). The making of a Salafi Muslim woman. Paths to conversion. New York, NY: Oxford University Press.

Konttori, J. (2015). Monsieur, näkemyksemme eivät ole samalta planeetalta! Poliittisen ja yhteiskunnallisen eliitin tulkintoja islamista ja kansallisesta identiteetistä musliminaisten pukeutumisesta käydyissä keskusteluissa 2000-luvun Ranskassa. Uskontotiede 15. Helsinki: Helsingin yliopisto, uskontotiede.

Kääriäinen, K. (2011). Religion and state in Finland. Nordic Journal of Religion and Society, 24(2), $155-171$.

Lövheim, M. (2012). Religious socialization in a media age. Nordic Journal of Religion and Society, 25(2), 151-168.

Martikainen, T., \& Latvio, R. (2018). Efforts to establish an imam-training programme in Finland. In M. Hashas, J. J. de Ruiter, \& N. V. Vinding, (Eds.), Imams in Western Europe. Developments, transformations and institutional challenges (pp. 411-430). Amsterdam: Amsterdam University Press.

Moore, D. L. (2007). Overcoming religious illiteracy: A cultural studies approach to the study of religion in secondary education. New York: Palgrave Macmillan.

Moore, D. L. (2015). Diminishing religious literacy: Methodological assumptions and analytical frameworks for promoting the public understanding of religion. In A. Dinham \& M. Francis (Eds.), Religious literacy in policy and practice (pp. 27-38). Bristol: Policy Press.

Nilsson, P.-E. (2018). Unveiling the French republic. National identity, secularism, and Islam in contemporary France. Studies in critical research on religion (Vol. 7) Leiden: Brill.

Pauha, T. (2017). Praying for one umma: Rhetorical construction of a global Islamic community in the facebook prayers of young finnish Muslims. Temenos: Nordic Journal of Comparative Religion, 53(1), 55-84.

Pauha, T. (2018). Religious and national identities among young Muslims in Finland: A view from the social constructionist social psychology of religion. Helsinki: University of Helsinki.

Pauha, T., \& Jasinskaja-Lahti, I. (2013). Don't ever convert to a Finn: Young Muslims writing about finnishness. Diaconia: The Journal for the Study of Christian Social Practice, 4(2), 172-193.

Pauha, T., \& Konttori, J. (2019). Finland. In O. Scharbrodt, S. Akgönül, A. Alibašić, J. S. Nielsen, \& E. Račius (Eds.), Yearbook of Muslims in Europe 10 (pp. 230-245). Leiden: Brill. 
Pauha, T., \& Martikainen, T. (2017). Lausunto Oasis-hankkeesta. Turku: Siirtolaisuusinstituutti.

Raittila, P., \& Maasilta, M. (2008). Silmäyksiä islamin esittämiseen suomalaisessa journalismissa. In T. Martikainen, T. Sakaranaho, \& M. Juntunen (Eds.), Islam Suomessa: Muslimit arjessa, mediassa ja yhteiskunnassa (pp. 225-243). Helsinki: SKS.

Rohe, M. (2019). Germany. In O. Scharbrodt, S. Akgönül, A. Alibašić, J. S. Nielsen, \& E. Račius (Eds.), Yearbook of Muslims in Europe 10 (pp. 293-310). Leiden: Brill.

Sorsa, L. (2015). Kirkkona valtiossa. Katsaus Suomen evankelis-luterilaisen kirkon valtiosuhteen edellytyksiin ja uudistuspaineisiin. Tampere: Kirkon tutkimuskeskus.

Taira, T. (2010). Religion as a discursive technique: The politics of classifying Wicca. Journal of Contemporary Religion, 25(3), 379-394.

Taira, T. (2013). The category of 'invented religion': A new opportunity for studying discourses on 'religion'. Culture and Religion, 14(4), 477-493.

Taira, T. (2019). Suvivirsi ja kristinuskon "kulttuuristuminen" katsomuksellisen monimuotoisuuden aikana. Uskonnontutkija-Religionsforskaren, 8(1). https://doi.org/10.24291/uskonnontutkija. v8i1.83000.

van der Veer, P. (1996). Writing Violence. In D. Ludden (Ed.), Contesting the nation: Religion, community, and the politics of democracy in India (pp. 250-269). Philadelphia: University of Pennsylvania Press.

Open Access This chapter is licensed under the terms of the Creative Commons Attribution 4.0 International License (http://creativecommons.org/licenses/by/4.0/), which permits use, sharing, adaptation, distribution and reproduction in any medium or format, as long as you give appropriate credit to the original author(s) and the source, provide a link to the Creative Commons license and indicate if changes were made.

The images or other third party material in this chapter are included in the chapter's Creative Commons license, unless indicated otherwise in a credit line to the material. If material is not included in the chapter's Creative Commons license and your intended use is not permitted by statutory regulation or exceeds the permitted use, you will need to obtain permission directly from the copyright holder.

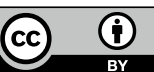

